\title{
Transapical aortic valve implantation: outcome in patients with low arithmetic risk profile
}

\author{
A Unbehaun*, M Pasic, T Drews, S Buz, S Dreysse, M Kukucka, A Mladenow, R Hetzer \\ From 23rd World Congress of the World Society of Cardio-Thoracic Surgeons \\ Split, Croatia. 12-15 September 2013
}

\section{Background}

Trancatheter aortic valve implantation (TAVI) has been introduced as an alternative treatment to eliminate aortic stenosis in patients who are at high risk for conventional surgery. Classical risk scores in cardiac surgery do not always reflect the true surgical risk. We analysed outcome and predictors of survival after TAVI in a large single-centre cohort with low arithmetic risk profile.

\section{Methods}

Between 04/2008 and 07/2012, 610 patients (median age 80, range 29-99 years) underwent transapical TAVI. Patients in cardiogenic shock were included $(\mathrm{n}=33$; $5.4 \%)$. In accordance with The-Society-of-ThoracicSurgeons-Predicted-Risk-of-Mortality (STS-PROMscore), the cut-off level between study and control group was arbitrarily set at $10 \%$. The study group of 274 patients (median STS-PROM-score 5.9\%, interquartile range [IQR] 4.4\%-7.6\%) was compared to the control group of 336 patients (median STS-PROMscore $18.0 \%$, IQR $13.5 \%-26.1 \%)$.

\section{Results}

Thirty-day mortality rate in patients with STS-PROMscore $<10 \%$ was $3.3 \%$. Survival in the study group was significantly better $(\mathrm{p}<0.001)$ with 1 -, 2 -, 3 -, and 4-year survival rate of $89 \% \pm 2 \%, 83 \% \pm 3 \%, 76 \% \pm 5 \%$, and $72 \%$ $\pm 6 \%$, respectively. Survival in a sub-group of 89 patients with STS-PROM-score $<5 \%$ was $95 \% \pm 3 \%$ and $91 \% \pm 5 \%$ at 1 and 3 years; $\mathrm{p}=0.002$. The strongest predictors of mortality in multivariate Cox-regression-analysis were advanced age ( $\mathrm{p}=0.003$, hazard ratio [HR] 1.08, 95\%-confidence-interval $[\mathrm{CI}]$ 1.03-1.14), higher NYHA class $(\mathrm{p}=0.027, \mathrm{HR} 2.54, \mathrm{CI} 1.12-5.81)$, and longer procedural time ( $\mathrm{p}=0.001$, HR 1.01, CI 1.01-1.01).

\footnotetext{
* Correspondence: unbehaun@dhzb.de

Deutsches Herzzentrum Berlin, Berlin, Germany
}

\section{Conclusions}

Regardless of their true surgical risk, patients with low arithmetic risk profile have much better survival after TAVI. This observation is a first prerequisite to broadening the indication for TAVI to patients with low risk for conventional surgery.

Published: 11 September 2013

doi:10.1186/1749-8090-8-S1-0321

Cite this article as: Unbehaun et al:: Transapical aortic valve

implantation: outcome in patients with low arithmetic risk profile. Journal of Cardiothoracic Surgery 2013 8(Suppl 1):O321.
Submit your next manuscript to BioMed Central and take full advantage of:

- Convenient online submission

- Thorough peer review

- No space constraints or color figure charges

- Immediate publication on acceptance

- Inclusion in PubMed, CAS, Scopus and Google Scholar

- Research which is freely available for redistribution
C Biomed Central 